\title{
Less Populist in Power? Online Communication of Populist Parties in Coalition Governments
}

\author{
Jakob Schwörer* (D) \\ Institute for Political Science, Leuphana University, Lüneburg, Germany \\ ${ }^{*}$ Corresponding author. Email: Jakob.schwoerer@leuphana.de
}

(Received 27 August 2020; revised 11 January 2021; accepted 15 January 2021;

first published online 10 March 2021)

\begin{abstract}
Recently several populist parties have become part of coalition governments in multiparty democracies, specifically in Western Europe. Based on the inclusion-moderation thesis, academics assume that incumbent populist parties tone down their populist rhetoric as a result of the daily businesses of deliberation and compromises in coalitions. However, while the assumption of tamed populists in power is widespread, there is little empirical work dealing with the topic. Using a classical quantitative content analysis of 1,210 Facebook posts published by populist parties in Italy, Spain, Austria and New Zealand, this article examines whether opposition parties are more populist and nativist than those in coalition governments. The findings indicate that populists do not decrease the degree of anti-elite and people-centred messages when they are in power but rather change the type of elites they attack and the antagonist groups they juxtapose. We should therefore rethink the validity of the inclusion-moderation thesis for populist parties in coalition governments.
\end{abstract}

Keywords: social media; populism; nativism; inclusion-moderation; government

There is little doubt about the rise of populism in the Western world, which is reflected in, among other things, increasing electoral successes for populist parties (Lewis et al. 2018). Yet, it is not only vote share but also government participation of populist parties that has increased (Albertazzi and McDonnell 2015). Most recently, countries such as Italy, Spain, Greece and Austria have experienced coalition governments with at least one populist actor involved. The most widespread definition understands populism as a thin ideology opposing a monolithic people with a corrupt elite, emphasizing popular sovereignty (Mudde 2004; Stanley 2008). Thus, attacks on political elites for being corrupt, selfish and not acting in the people's interests while at the same time praising the supposed people's attitudes and actions are definitive communication features of this party type (Ernst et al. 2019a; Rooduijn et al. 2014). Scholars assume that these kinds of discourses change as soon as populists enter national governments (Akkerman 2016; Bernhard 2020;

(C) The Author, 2021. Published by Cambridge University Press on behalf of Government and Opposition Limited. This is an Open Access article, distributed under the terms of the Creative Commons Attribution licence (http://creativecommons. org/licenses/by/4.0/), which permits unrestricted re-use, distribution, and reproduction in any medium, provided the original work is properly cited. 
Krause and Wagner 2019). The so-called inclusion-moderation thesis - originally established to explain moderation effects on religious parties - suggests that participation in coalition governments tames populists' communication practices as they are constrained to deliberate and make compromises. Incumbent populists struggle with their image as political outsiders because engagement in the daily business of bargaining is expected to have a taming effect on them (Krause and Wagner 2019). Yet, while the inclusion-moderation thesis is widespread among political science scholars, we lack empirical evidence supporting this assumption. So far, single case studies and anecdotal evidence are the only empirical foundation the thesis can rely on.

Four populist forces recently entered national government coalitions in Western Europe - the Italian Five Star Movement (M5S), the League (Lega), the Spanish Podemos and the Freedom Party of Austria (FPÖ) - providing excellent cases for an analysis of populist parties' communicative content in opposition and in power. The same holds true for New Zealand First (NZF), a populist right-wing party that recently participated in a coalition government with the New Zealand Labour Party after being in opposition for several years.

This work contributes to the theoretical and empirical discussion about the consequences of populism in power by adding changes in populists' own discourses to more widely assessed political domains such as government actions, democratic quality and shifts of public attitudes (Albertazzi and McDonnell 2015; Huber and Schimpf 2016; Williams 2018). Thereby, I build on measurements of degree (or quantity) of populist and nativist communications (Ernst et al. 2017; Rooduijn et al. 2014; Schwörer 2021), assessing whether different populist actors use populist and nativist discourses more frequently during periods in opposition or in government, distinguishing between different targets of populists' verbal attacks (Fernández-García and Luengo 2018).

This article is structured as follows: I first provide a definition of populism and nativism and a first rough operationalization of these concepts. I then describe the key assumptions from the inclusion-moderation thesis, the state of research regarding populists' discourses in government as well as hypotheses deriving from the inclusion-moderation thesis and from negative campaigning literature. After describing the methodological approach and the selection of cases, I start with the analysis. In sum, the findings rather question the original assumption that incumbent parties are less populist. Building on a fine-grained measurement of populist elements, we see that discourses change slightly but do not necessarily become less populist.

\section{Populism and nativism}

This study refers to the definition provided by Cas Mudde (2004: 543) that understands populism as 'an ideology that considers society to be ultimately separated into two homogeneous and antagonistic groups, "the pure people" versus "the corrupt elite", and which argues that politics should be an expression of the volonté générale (general will) of the people'. While there are lively discussions about the ideological nature of populism (Aslanidis 2016), there is less disagreement on the fact that populist discourses exist (Aslanidis 2016; Decker and Lewandowsky 2017; Hawkins et al. 2012; Wolinetz and Zaslove 2018). 
Several academics have created new perspectives for research on populism by focusing on its communicative content (Jagers and Walgrave 2007; Reinemann et al. 2017). As a consequence, the focus shifted 'from what constitutes the ideology of populism to how it is communicated' (De Vreese et al. 2018: 425). Populist ideas are expressed in order to create their intended effect on the audience and are therefore 'mostly reflected in the oral, written, and visual communication of individual politicians, parties, social movements' (Reinemann et al. 2017: 13).

Two general perspectives on populist communication exist. First, scholars focus on how something is communicated and examine stylistic and linguistic features such as negativity, crisis rhetoric or emotionality (Ernst et al. 2019a). So far, there has been very little research in this respect (Ernst et al. 2019a) - which might also be due to difficulties related to quantitative measurement of these elements. A second strand of literature refers to the content of populist communication referring to what is communicated. The core discursive elements are derived from Mudde's ideational definition of populism. While populist ideology reflects a political worldview, a 'set of basic assumptions about the world' (Hawkins et al. 2012: 3), populist communicative content can be considered as the respective vocal and written expression of it. ${ }^{1}$ Werner Wirth et al. (2019: 7) define this sort of populist communication as 'acts of communication aimed at expressing populist ideology by being conflictive toward the elite and advocative toward the people. Specifically, populist communication may be characterized as people-centrist, antielitist and aimed at restoring the sovereignty of the people.'

An increasing number of studies attempt to measure populist content in parties' political texts by identifying discourses that portray elites in a negative way and as not acting in the people's interest while praising the values and actions of the people (Ernst et al. 2017, 2019a; Manucci and Weber 2017; Rooduijn et al. 2014). Since I am interested in whether the populist content of parties decreases in government I adopt this approach. Yet, the question of who or what is portrayed as elite is often not particularly clearly described in empirical studies. Belén Fernández-García and Óscar Luengo (2018) identify political elites such as politicians and parties, economic actors such as multinational corporations and the rich or media elites (see also Schwörer 2016). Matthijs Rooduijn et al. (2014: 567) highlight that populist anti-elitism 'target[s] elites in general' and not single politicians or parties (see also Manucci and Weber 2017; Schwörer 2021). As explained in the methodological section, this article distinguishes between criticisms of single and whole elites as well as between political, economic and other types of actors in order to provide a more fine-grained analysis of populist blame attribution. It is important to note that populism should not be considered 'as an "all or nothing" affair but as a matter of degree' allowing 'a continuous measure' (Meijers and Zaslove 2020: 8). Compared with competing non-populist actors, the amount of populist messages usually remains higher among 'true populists', which justifies their ideological classification (Ernst et al. 2019b; Schwörer 2021). ${ }^{2}$

As well as populist discourses, this article further measures nativist elements within Facebook posts by two populist radical right parties (FPÖ and Lega) and the right-wing but not fully nativist populist party NZF. Nativism (Mudde 2007) or ethnic nationalism (Pauwels 2014; Rydgren 2017) are considered host ideologies and are defined in very similar terms. According to Mudde (2007: 19), nativism is 
an ideology 'which holds that states should be inhabited exclusively by members of the native group ("the nation") and that nonnative elements (persons and ideas) are fundamentally threatening to the homogenous nation-state'. Thus, besides the elites, nativist populism further excludes other groups from the people, based on cultural, religious or national traits (Schwörer and Fernández-García 2020). It should be emphasized that the exclusion of non-native outgroups is a trait of the radical right and not of populism itself: 'while exclusionism is a central feature of radical right-wing populism, it is not part of populism per se' (Rooduijn et al. 2014: 564).

\section{Inclusion-moderation effects on populist parties in government?}

Scholars widely assume that entering government changes the discourses of populist parties. Originally developed for and applied to religious parties, the inclusionmoderation thesis 'holds that participation in democratic institutions and procedures will amend the radical nature and ideology of political parties' (Akkerman et al. 2016: 3). This is explained by two factors (Akkerman et al. 2016; Berman 2008). First, traditional rational-choice approaches assume that parties competing for votes attempt to catch the median voter in the middle of the political spectrum (Downs 1957). As office-seekers, populist parties are inclined to soften their discourses and demands in order not to scare off voters and to appeal to a broader electorate that will enable them to stay in power. Yet, this argument can hardly be considered valid for most Western European multiparty systems with coalition governments where populist parties share power with others and do not have to achieve a large majority in order to remain in office. Second, inclusion in office is often associated with a moderation effect when respective parties take part in coalition governments (Akkerman et al. 2016; Bernhard 2020). In this sense, deliberation and compromises with coalition partners (and veto players) are a necessity in order to survive as a government. Werner Krause and Aiko Wagner (2019: 3) argue that populists entering governments 'cannot avoid becoming part of the daily business of legislative bargaining and deliberation. As a consequence, more established populist parties will be under pressure to soften their anti-elite appeals.' Among different forms of political behaviour, populist parties' political communication is especially expected to be influenced by moderation effects (Akkerman et al. 2016; Bernhard 2020; Krause and Wagner 2019).

Summarizing the findings from several case studies dealing with the life-cycle of populist parties, Tjitske Akkerman (2016: 277) concludes, 'in many cases, officeseeking or participation induces the parties to adapt their role in parliament. They moderate their lone opposition and increasingly cooperate with other parties in parliament. Various parties have acted as trustworthy coalition partners and demonstrated the ability to conform to political rules and mores.' This is also reflected in changes regarding populist parties' anti-establishment orientation (Akkerman 2016: 277). In sum and applied to the communication practices of populist parties, the inclusion-moderation thesis suggests there will be a decline in populist discourses once a respective party enters a coalition government.

Yet, despite suggestions to 'look more carefully at if and how populist discourse changes once these parties are in government' (Polk et al. 2017: 367), we are still 
confronted with very little empirical evidence in this respect. Several studies examine the consequences of populists in power but do not focus on discourses of populists themselves. Daniele Albertazzi and Sean Mueller (2013) assess the consequences of populists in government in Austria, Italy, Poland and Switzerland for liberal democracy, stating that their policies and actions contradict the tenets of liberal democracy, such as the principle of power limitation and individual rights. Similar conclusions are drawn by quantitative studies from Latin America (Huber and Schimpf 2016). The edited volume published by Daniele Albertazzi and Duncan McDonnell (2015) addresses further aspects. Focusing on electoral consequences, the authors found that government participation does not necessarily lead to electoral decline. Moreover, unlike existing assumptions to the contrary, populists in power are able to achieve policy successes and their role in government 'can be positively evaluated by populist representatives and members' (Albertazzi and McDonnell 2015: 173). Similar findings come from quantitative comparative studies (Van Spanje 2011). Also Tjitske Akkerman and Sarah De Lange (2012) show that incumbent populist radical right parties might achieve policy goals and do not necessarily lose votes. Franz Fallend and Reinhard Heinisch (2016) assess the effect of strategies against incumbent populist parties, claiming that incorporating the FPÖ in government has been an effective strategy to weaken its electoral success.

This short literature review has stressed the different dimensions covered by current research on incumbent populist parties. The consequences on populist parties' discourses themselves have so far been addressed by very few studies even though the inclusion-moderation thesis - as formulated by several scholars - explicitly assumes a taming effect of government participation on populist parties' political communication. Krause and Wagner (2019:4) associate shifts in 'antiestablishment discourse' and 'communication styles' with inclusion-moderation effects, and Laurent Bernhard (2020: 211) discusses 'political communication'.

Among the few studies addressing discursive moderation effects on populist parties, Akkerman et al. (2016) offer a longitudinal analysis of anti-elite discourses by radical right populist parties based on automated word-counting of anti-elite keywords in election manifestos. They claim that anti-establishment discourses increased particularly since the 2000s; however, they did not control for the effect of government participation. They further assessed other dimensions of populist radical right parties' agendas and communications such as 'radical positions on core issues, salience of cultural issues, and anti-establishment positions', concluding that 'on all three dimensions ... the average trends do not indicate that radical right-wing populist parties have mainstreamed' (Akkerman et al. 2016: 48), yet, again without explicitly taking into account incumbent effects. So far, only Bernhard (2020) has explicitly examined populist communication of incumbent and opposition parties. In his case study of the populist Geneva Citizens' Movement he conducts a quantitative content analysis of the party's newspaper before and after coming into office. His measurement of populism is based on Mudde's definition and consists of anti-elitism, people-centrism, popular sovereignty and antagonisms. Confirming the inclusion-moderation thesis, the findings indicate that the party indeed uses a higher degree of populist rhetoric in opposition than in government. 
In sum, we are confronted with an increasing number of studies concerned with the performance and consequences of populists' government participation but with very little empirical evidence regarding the validity of the inclusion-moderation thesis for populists' communication. But how exactly should we expect populist parties to change their discourses? Therefore, we need to distinguish between different types of discursive elements assessed in this study: nativism, pro-people messages, anti-elite discourses and antagonisms.

Let us start with nativist messages against supposed non-native others and immigration constituting communicative features of radical right parties. In this regard, we should have a closer look at the underlying arguments from the inclusion-moderation thesis. Whether deliberation and compromises are expected to tone down populist radical right narratives might primarily depend on the coalition partner and its ideological orientation. Issues that radical right parties and voters promote and prefer are not that far from the centre right compared with more leftist parties (Green-Pedersen and Mortensen 2015; Walgrave and De Swert 2007). Studies found that right-wing mainstream parties in particular do not refuse to adopt the anti-immigration stances of the radical right (Abou-Chadi 2014; Schwörer 2021). In other words, if the radical right party's coalition partner itself is sceptical towards immigration, nativists do not need to tone down their discourses. This should not apply to right-wing populist parties that join a coalition with more leftist parties, as NZF did with Labour in New Zealand. In line with Krause and Wagner (2019), compromises are necessary in coalition governments in order not to endanger the existence of the coalition. Since nativist parties are ideologically closer to the centre right, respective discursive compromises are less necessary. However, an emphasis on nativist messages in coalition with the centre left may lead to a loss of votes from the core constituency of the latter, causing internal coalition trouble. Understanding parties as officeseekers (Downs 1957), NZF should have no interest in threatening the coalition by provoking the centre left with anti-immigration or anti-outgroup messages. In this regard the Lega and FPÖ should not be expected to decrease their nativist discourses in government since neither the M5S as coalition partner of the Lega nor the centre-right People's Party (ÖVP) in Austria reject nativist messages (Schwörer 2016, 2021).

Hypothesis 1a: Lega and FPÖ do not decrease the amount of nativist messages once in coalition government.

Hypothesis 1b: NZF decreases the amount of nativist messages in coalition with the centre left.

Regarding messages deriving from the populist orientation of these parties, we should first distinguish between those targeting an elite and those appealing to the people. Starting with the latter, populists emphasize the positive character and behaviour of the people, portray the people as a monolithic entity, demonstrate their own closeness to the people, stress the people's role as victim and demand measures in favour of the people (Ernst et al. 2019a; Schwörer 2021). Considering these references, the inclusion-moderation thesis does not seem to 
apply. First, these discourses do not follow a radical or far-right logic and might appeal to a broader electorate rather than to political fringes. Furthermore, these references are discourses which do not necessarily imply concrete policies - except where they demand measures for the people - and might therefore be maintained in government (Schwörer 2021). Thus, Hypothesis 2 is as follows:

Hypothesis 2: Populist parties in government are not less people-centred than in opposition.

Regarding anti-elite discourses, the picture is more complex. What elites actually are is often hardly defined in empirical research. Some scholars distinguish between political, economic, cultural and media elites (Fernández-García and Luengo 2018; Schwörer 2016). As indicated above and described in more detail in the method section, this study builds on these concepts and further distinguishes between 'single' and 'whole' elites. The political elite seems to be the unifying target of all populist parties (Schwörer 2021). In this respect it is argued that criticizing all political opponents - for example, 'the parties' and 'the politicians' or 'the establishment' - characterizes populist criticisms and distinguishes it from discourses by other parties (Manucci and Weber 2017; Rooduijn et al. 2014). Akkerman (2016: 277) summarizes the findings from several case studies within her edited volume, stating that populist parties' 'anti-establishment behaviour clearly changes when pursuing office or when participating in government'. Jonathan Polk et al. (2017: 2) also assume that 'the salience of anti-establishment and anti-corruption rhetoric will be greater ... for parties in opposition than for those in government'. Besides being forced by the coalition partner to soften anti-elitist messages, the simple fact that populists are in power is often perceived as a paradox to their main communicative features. In this sense, Jan-Werner Müller (2016: 41) summarizes the supposed academic view on this question: 'Conventional wisdom has it that populist parties are primarily protest parties and that protest cannot govern, since one cannot protest against oneself.' I therefore formulate the following hypothesis.

Hypothesis 3: Populist parties in government are less likely to target the whole political elite than when they are in opposition.

Furthermore, populists are expected to criticize single parties, politicians or the government more frequently than others (Nai 2018). In this respect, literature on so-called negative campaigning is useful in order to find respective assumptions. Negative campaigning refers to rhetorical attacks and criticism of political opponents or, as formulated by John Geer (2006: 23), 'negativity is any criticism levelled by one candidate against another during a campaign'. In this respect, scholars assume that the opposition relies more on negative campaigning than incumbent parties do (Haselmayer 2019). According to Martin Haselmayer (2019: 361), the underlying logic is that governing parties 'benefit from their ability to emphasize their record in government and should therefore run rather positive campaigns'. Thus, governing parties might still use negative campaigning - a critique of single parties or politicians - but to a lesser degree than the opposition, whose main task per definition is 'criticizing government failure' (Haselmayer 2019: 357). 
Hypothesis 4: Populist parties in government criticize single political actors less often than when they are in opposition.

According to many scholars, a decisive feature of populism is not only rejecting the political elite and praising the people but also stressing the antagonism between these groups. As Mudde (2004: 543) states, populism 'considers society to be ultimately separated into two homogeneous and antagonistic groups, "the pure people" versus "the corrupt elite". Accordingly, the antagonism between people and elites is a decisive feature of most empirical measurements of populism (Bernhard 2020; Manucci and Weber 2017; Rooduijn et al. 2014). Here the same argument applies as for Hypotheses 3 and 4. Since populist parties are expected to tone down their anti-elite statements in government, it is also more likely that they juxtapose the people less often with elites. The last hypothesis is therefore as follows:

Hypothesis 5: Populist parties in government are less likely to construct an antagonism between the people and the elite than populist parties in opposition.

\section{Research design}

For the purpose of this study, parties need to be selected which are populist and which took part in government. More specifically, the inclusion-moderation thesis is mostly expected to apply to populists in coalition governments since coalitions require some sort of compromise and deliberation expected to tame populists' discourses (Akkerman et al. 2016; Bernhard 2020). In this sense, I rely on a most similar systems design focusing on populist parties' discourses in opposition and in coalition governments.

As described below, I focus on communication on Facebook, which requires current cases since social media has been used as a political campaigning tool only in the course of the last decade. Of Western European multiparty systems, there are three countries that have recently experienced a (partially) populist government: Italy, Spain and Austria. The parties involved are M5S, Lega, Podemos and FPÖ - all classified as populist by experts (Rooduijn et al. 2019). As mentioned above, this implies that political discourses about elites and the people are much more widespread among these parties than among other party types (see also Ernst et al. 2019b). In Italy, the M5S formed a coalition with Lega (1 June 2018 to 4 September 2019) before the latter left the coalition and the M5S decided to form a government with the centre-left Democratic Party on 5 September 2019, which is still in office at the time of writing. In Spain, Podemos entered a coalition with the social democratic party (PSOE) on 13 January 2020 (ongoing). In Austria the FPÖ built a coalition with the centre-right ÖVP on 18 December 2017 which lasted until the end of May 2019, when the publication of a secretly recorded video revealed corruption tendencies among the former vice chancellor of Austria and leader of the FPÖ Heinz-Christian Strache, which led to the end of the coalition. Furthermore, in New Zealand, the right-wing populist NZF entered a coalition with the Labour Party in 2017 after years in opposition. NZF, characterized as populist and nationalist (Duncan 2018), attacks 'the usual suspects - "the 
elite," immigrants, "cultural Marxists" as well as journalists (Moffitt 2017: 128). While the populist orientation - the principal selection criteria for this study - is hardly questioned by scholars (Donovan 2020; Duncan 2018; Moffitt 2017), some academics argue that NZF does not emphasize nativist standpoints to the same extent as its European counterparts (Barker and Vowles 2020; Donovan 2020). Like Italy, Spain and Austria, New Zealand is a parliamentary democracy with a multiparty system characterized by coalition governments. At this point, it should be clarified that some countries - for example those in Eastern Europe are not part of the sample since the methodological approach described below requires a deep knowledge of the language in which the statements are produced, which restricts case selection to certain countries. ${ }^{3}$

I analyse the contents of communications of the mentioned parties for periods of three months in opposition and in power. In order to exclude potential factors that might influence the degree of populism in party communications, 'comparable' time units are selected. As one important factor, party leadership did not change between these periods and no national (or European) elections took place during or shortly after the periods examined. In Spain, periods are selected shortly after government formation since Podemos entered government only recently. The two periods are still comparable since in both cases communication is measured starting on the day when the new prime minister was appointed. Furthermore, for the Spanish case I exclude the legislative period of the centre-left government from June 2018 until January 2020. The centre left came into office not by elections but through a constructive vote of no confidence - supported by Podemos - and experienced a governmental crisis and the European elections in 2019, putting the country into an ongoing election campaign. Thus, in order to select time periods in a less unique political environment, I choose the beginning of the legislative period under Prime Minister Rajoy (II) as the opposition period for Podemos. A detailed table with descriptions of the case selection can be found in the Online Appendix.

Populist communication is measured on the basis of posts published by official party profiles on Facebook. Facebook posts are preferred over messages on Twitter for two reasons. First, Facebook allows longer messages than Twitter and might therefore contain more developed communicative content. To make the samples more comparable, simple announcements of events and posts lacking political content have been excluded as suggested by previous studies (Schwörer and Romero-Vidal 2020). The length of the messages does not vary considerably across the sample - even less within the same party profiles. It is only the Italian M5S that occasionally posted content consisting of more than five sentences; however, this does not affect comparability: the research design is based on inner-case comparisons, meaning that data from the M5S is compared across time and not primarily with other parties. But even the latter is possible: As Facebook posts commenting on political developments and opponents have an almost similar structure, they are considered an adequate source for measures of populism and nativism and are generally used for cross-party comparisons (Ernst et al. 2017; Schwörer and Romero-Vidal 2020; Stier et al. 2017).

Second, Twitter changed the limit of characters from 140 to 280 in 2017. Since the sample includes periods before and after 2017, comparability - even within the same party profile - might be doubted. The application 'Facepager' has been used 
in order to collect messages from the party accounts on Facebook (Jünger and Keyling 2018). Only the Lega posts had to be gathered manually. The unit of measurement is the single post, meaning that the final score for each period reflects the percentage of posts containing a specific discourse (e.g. against all elites). In total 1,210 posts from the five populist parties have been coded. Compared with works measuring related concepts in populists' discourses relying on 70 posts on Facebook per party (Schwörer and Romero-Vidal 2020) or on three to four speeches per politician (Hawkins et al. 2019), the sample of posts per party selected for this study is more extensive.

While I argue that social media platforms such as Facebook are a suitable source for measures of populism since they 'have become major campaigning tools, allowing direct communication from parties and candidates to voters without the mediation role of mass media' (Schwörer and Romero-Vidal 2020), the limits of this approach should be stressed as well. Social media platforms do not cover more formal communicative content such as one might find in election manifestos. Moreover, due to the absence of journalistic interference it is sometimes assumed that high degrees of populism are caused by the nature of social media itself and its high 'potential for unfiltered, unrestricted populism' (Ernst et al. 2019b). Social media can create protected spaces for parties and their followers where populist and more extremist messages are shared without hesitation (Krämer 2017). However, recent studies reject the assumption that Facebook and Twitter contain more populist communicative content than, for example, statements from party politicians in newspapers (Ernst et al. 2019b). Nevertheless, it should be admitted that despite the fact that populism as communicative content can be found in very different types of political texts (Ernst et al. 2019b; Hawkins et al. 2019) - and to a very considerable extent even in election manifestos (Manucci and Weber 2017; Schwörer 2021) - this study cannot make any statements about moderation effects in forms of communication platforms other than Facebook.

I measure populist messages using a quantitative classical content analysis (Rooduijn and Pauwels 2011). I code negative references to elites as well as positive references to the people, mostly relying on a codebook from previous studies (Schwörer 2021). Regarding anti-elitism, I distinguish between references to the entire (e.g. 'the parties'; 'the politicians'; 'all the others' etc.) and single (politician $\mathrm{XY}$; party XY etc.) political elites and negative evaluations of the government. As mentioned above, scholars assume that a rejection of the entire political elite is a communicative feature of populism (Bernhardt 2020; Manucci and Weber 2017; Rooduijn et al. 2014), while criticizing single elites or relying on negative campaigning is also done by other political actors, albeit to a lower extent (Nai 2018). The distinction between 'single' and 'entire' is further applied to other kinds of elites. Besides political elites, negative evaluations of economic actors (single actors such as single enterprises; whole actors or a branch of enterprises such as banks; the rich) and the media (single journalists or TV channels; whole media such as all journalists or TV channels) are coded as well.

The same logic applies for positive evaluations of the entire people (the citizens; the population etc.) or subgroups (workers; tax payers; 'many' etc.). The antagonism between different types of elites and the people is measured as a further category since 'the emphasis on a societal divide between the ordinary people and 
the corrupt elites has been referred to as the essence of populism' (Hameleers 2020: 3). Hence, those statements containing a positive reference to the people and a negative reference to elites or supposed non-natives is classified as 'antagonism' when the conflicting nature of these groups is emphasized.

Regarding nativist communication, I measure negative evaluations of religious, cultural or national groups (or simply immigrants or refugees). Anti-immigration messages are coded as another subtype of nativist messages (Schwörer 2021). A detailed description of all categories including example sentences can be found in the Online Appendix. For the purpose of reliability a second person was instructed to code a sample of statements according to people-centred and antielitist categories. The percentage agreement of sentences that have been assigned to the main categories at least by one of the coders is very high. ${ }^{4}$ The same is true for Cohen's Kappa, which is almost perfectly consistent (Landis and Koch 1977). ${ }^{5}$

\section{Analysis}

Starting with Hypothesis 1a, radical right populist parties indeed do not seem to decrease the amount of nativist statements in government, as Figure 1 shows. It illustrates the percentage of posts containing nativist messages. The Italian Lega and the Austrian FPÖ even used a slightly higher number of discourses against immigrants and immigration during their participation in a coalition with partners (M5S and ÖVP) which at least do not reject nativist content (Schwörer 2016; Schwörer and Fernández-García 2020). As expected, NZF is more nativist in opposition than in government with the centre left. Compared with the Lega and FPÖ, NZF appears generally less hostile towards immigration and immigrants (Vowles 2020). ${ }^{6}$ In sum, the ideological orientation of the coalition partner seems to play a crucial role regarding the taming effect of nativist messages in government even though the number of cases is still too small to draw a general conclusion. Interestingly, the Lega decreased its amount of nativist messages considerably when it moved to opposition after leaving the coalition with the M5S. As we will see in what follows, this lack of nativist blame attribution has been compensated by a strong emphasis on anti-elite messages.

Regarding pro-people messages, we need to distinguish between references to the people as an entity (the 'whole' people) and references to subgroups within the people. Figure 2 illustrates the values for both types of people-centred messages as well as a score labelled 'all references'. This shows the percentage of posts containing either a reference to the whole or to subgroups within the people. As assumed by Hypothesis 2, we do not see a clear difference between the percentage of people-centred references in opposition and in power, which is also confirmed by an independent $t$-test. ${ }^{7}$ The FPÖ refers more often to the whole people in government than in opposition, while a different picture emerges regarding Podemos's communication on Facebook. The latter refers less often to all citizens in government but instead increases its references to specific subgroups, especially to workers and pensioners. The share of NZF's references to the people remains almost the same in power. Figure 2 further illustrates that both populist radical right parties have much lower people-centred scores than M5S and Podemos while NZF as a 


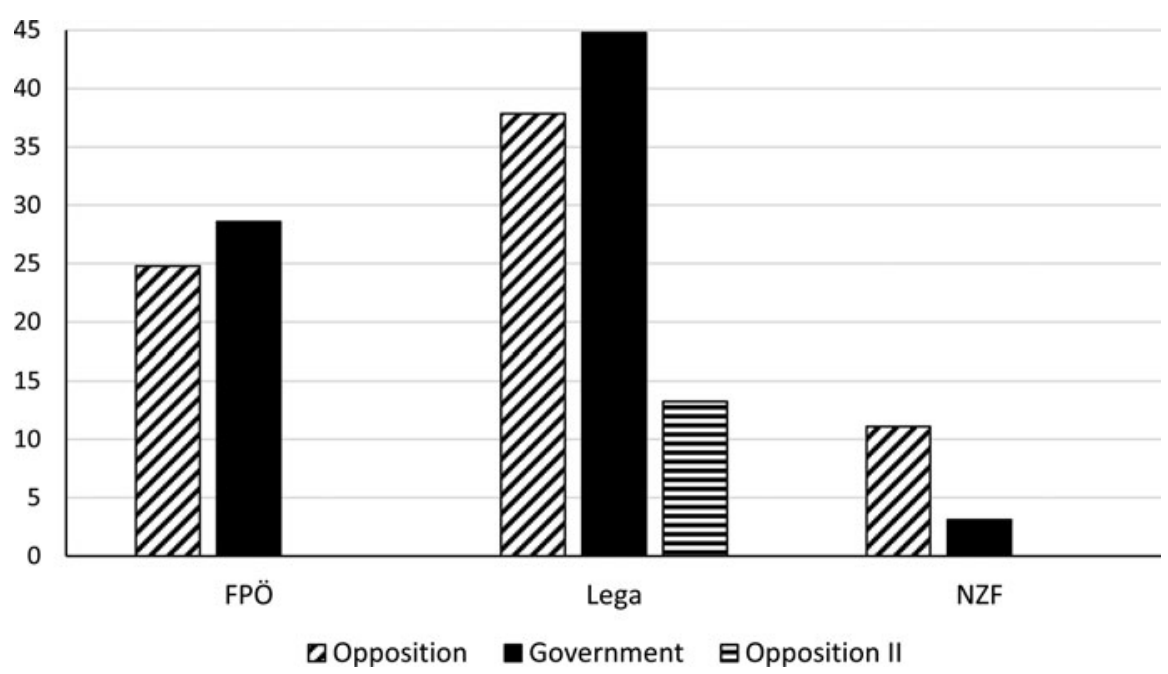

Figure 1. Nativist Messages in Government and in Opposition (percentages of posts) Note: The $y$-axis indicates the percentage of posts on Facebook coded as nativist.

right-wing but not fully nativist party takes an intermediate position. The M5S's communication particularly relies on positive references to the people - both to single subgroups and the population as a whole.

Moving on to anti-elite messages, parties in power are expected to be less likely to target the whole political elite than in opposition (H3). Moreover, the same should be observed for attacks on single parties and politicians (H4). Figure 3 illustrates that most populist parties do not criticize politicians in general but focus on attacks on single competitors or the government. Among the parties examined only the M5S criticizes the whole political establishment to a considerable extent. Yet, regarding this case, Hypothesis 3 seems to apply and the findings for NZF and the FPÖ at least point in the same direction: The entire political elite is less often criticized when the party is in government. Hypothesis 4 cannot be confirmed, which is also reflected in a respective independent t-test. ${ }^{8}$ Neither the FPÖ or M5S nor the Lega decrease their attacks on single political elites in government compared with the previous opposition period. In the case of the Italian Lega, we see a very considerable increase in anti-elite messages when the party left the government, while its 'first' opposition period is characterized by the lowest percentage of anti-elite messages. Podemos and NZF are the only parties that decrease their critique of political opponents considerably in government.

But which actors are criticized by populists? Unsurprisingly, the radical right FPÖ and Lega turn their negative campaigning towards left-wing parties (including the Greens), in particular towards the largest centre-left parties in the countries. Podemos emphasizes negative evaluations of the centre right in 2016 and in 2020 - after the electoral breakthrough of Vox -the radical right. Naturally, populists in power do criticize the government less often than do populists in opposition. Nevertheless, anti-government discourses are still present in Facebook posts of 

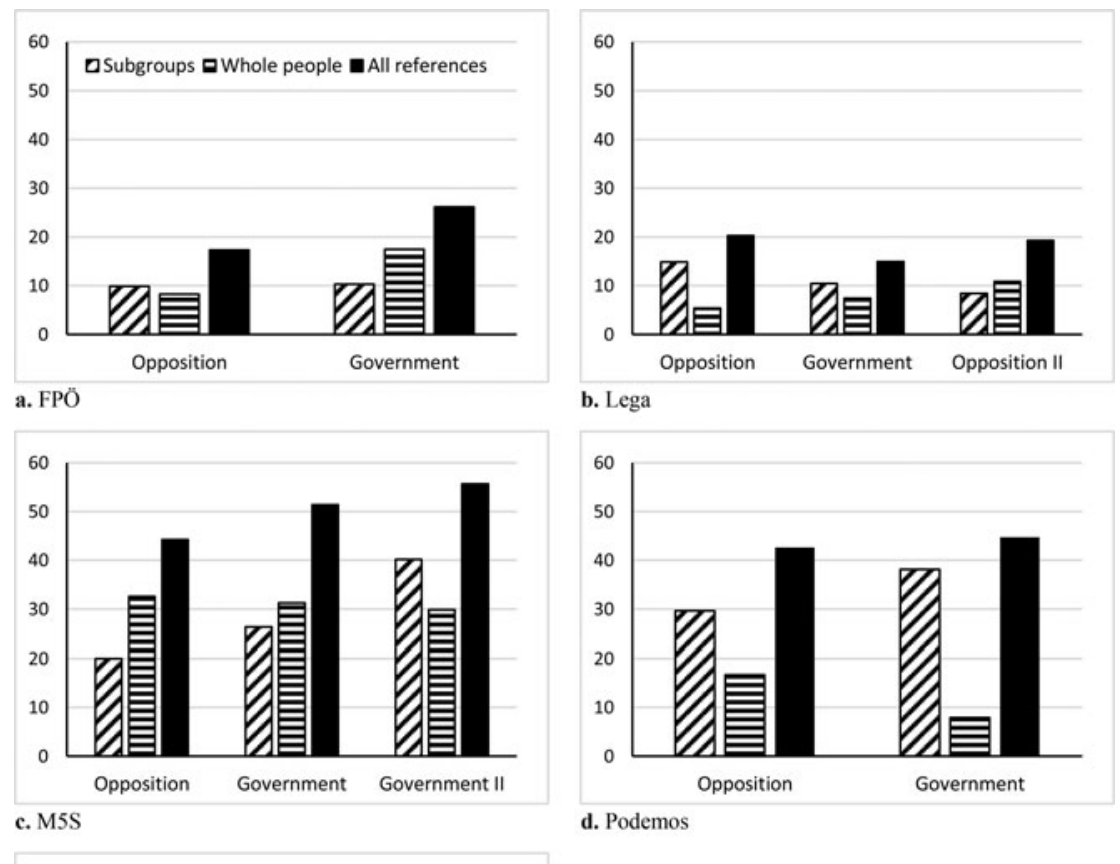

d. Podemos

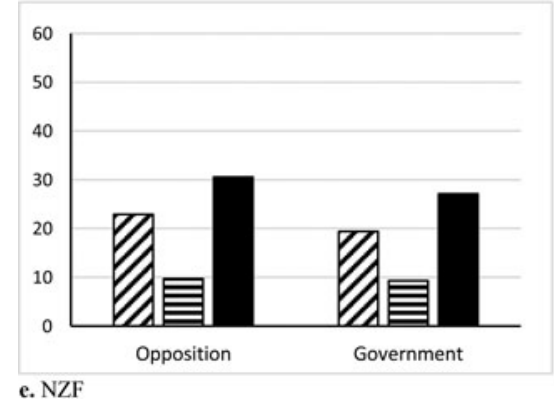

Figure 2. People-Centred Messages in Government and Opposition (percentages of posts containing references to subgroups, the whole people or one of these elements)

most incumbent populist parties. Instead of attacking the current government, previous or regional governments and ex-ministers are blamed for negative developments. Populist parties compensate for a lack of messages against the government by criticizing other political actors more often - such as left parties and politicians (FPÖ; Lega; M5S in its first government) or the radical right (Podemos; M5S in its second government) - depending on their coalition partner. NZF, for example, hardly ever attacks the centre left but frequently the centre-right government (in opposition) or the centre-right opposition (in government) (see Online Appendix).

Beside political elites, economic and media actors are sometimes negatively evaluated. Yet, as Figure 4 indicates, political elites are the main target of populists' accusations. The M5S attacks economic elites quite often, in up to $20 \%$ of its Facebook posts in coalition with the centre left, and Podemos and NZF are also 

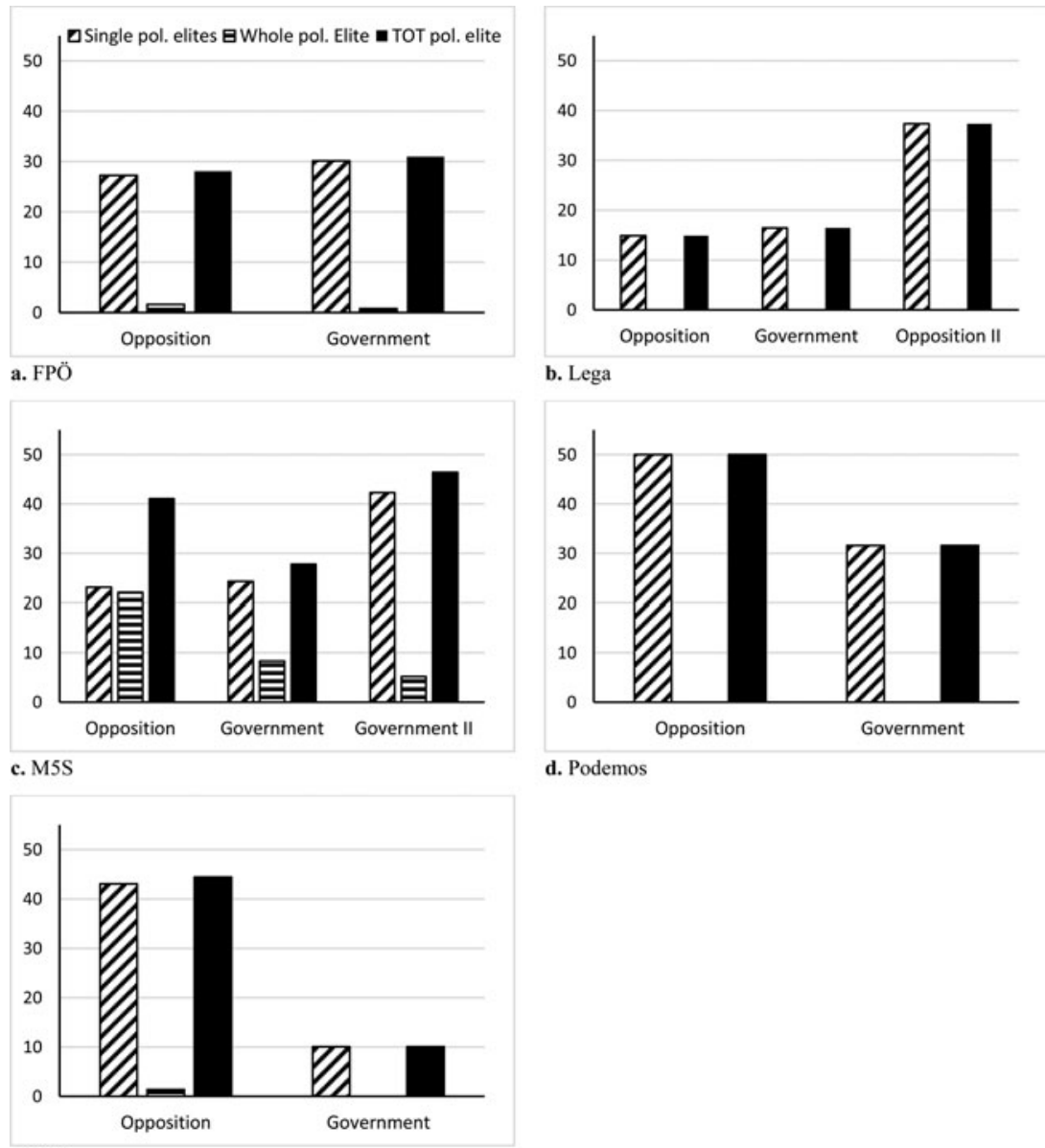

d. Podemos

e. NZF

Figure 3. Anti-Elitist Messages in Government and Opposition (percentages of posts containing references to single political elites, the whole establishment, or one of these elements)

frequently engaged in criticizing economic targets (yet not as often as political elites), while the two radical right parties (Lega and FPÖ) hardly ever do so. Yet, attacks towards economic actors by the M5S and Podemos do not seem to depend on governmental or opposition status. Regarding the media, the picture is slightly diverse: the FPÖ, Podemos and NZF criticize media actors more often in government - yet Podemos and NZF do so only once. The M5S attacked the media very frequently during its coalition with the Lega but refrained from doing so when in power with the centre left. Thus, only some populist parties may attack new nonpolitical elites when they come into office.

After confirming Hypotheses 1, 2 and 3 and rejecting Hypothesis 4, we now move on to the last one. A core feature of populism is the construction of a societal divide between the people and elites. In this sense, populist parties in government should be less prone to construct an antagonism between the people and the elite. 


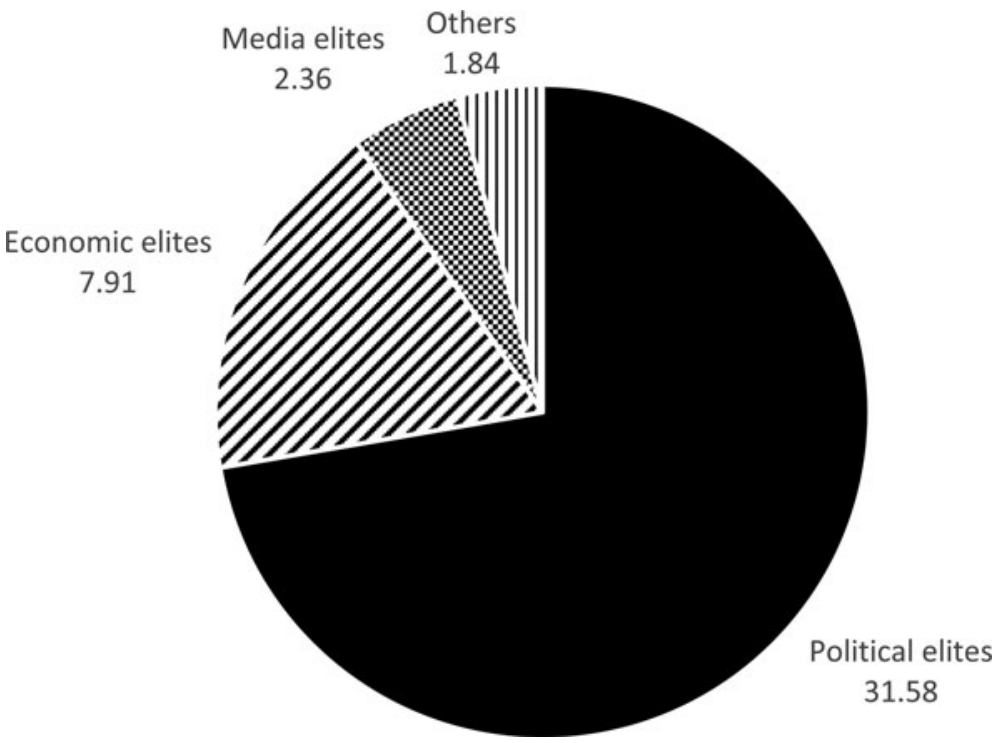

Figure 4. Average Percentage of Critique of Different Types of Elites

Note: Mean percentages of negative references to respective elites. SD political elites $=12.95$; SD economic elites = 6.28; SD media elites $=2.23$; SD others (unspecific elites, cultural elites or party enemies) $=2.8$.

Table 1 illustrates the percentages of all antagonisms constructed by populist parties. They might consist of divides between the people and political elites (single or whole), economic or media elites (single or whole) or supposed non-native outgroups (nativist antagonism). Table 1 reveals that antagonisms are part of populists' discourses both in government and in opposition, which is reflected in the respective t-test. ${ }^{9}$ The incumbent FPÖ substantially increases the number of posts setting the people against negative counterparts. A similar development can be observed among the M5S during its coalition with the centre-left Democratic Party. Regarding Podemos and more considerably NZF, antagonisms play a less important role in power.

Table 2 distinguishes between different targets opposed to the people. Taking a closer look at political elites as counterpart, there is hardly a substantial difference in the degree of these discourses between incumbent and opposition parties, which is confirmed by a respective independent t-test. ${ }^{10}$ It is true that the Lega merely juxtaposes the people with the political elite in opposition, but it only does so after it has left the coalition with the M5S. In the other periods, the party mostly mentioned supposed violent attacks by immigrants on members of the native society, such as bus drivers (e.g. 13 August 2017), young women (e.g. 31 August 2017) or women with disabilities (e.g. 20 August 2017). After leaving the coalition, the party creates a cleavage between the national and regional governments led by political adversaries on one side and the people on the other, stating, 'this government continues to mock the Italians' (31 October 2019). The fact that the Lega hardly ever emphasizes the cleavage between the people and political elites further questions the party's characterization as populist party. The M5S sets the people (or 
Table 1. Percentage of All Antagonisms Constructed by Populist Parties

\begin{tabular}{lcccc}
\hline & Opposition & Government & Opposition II & Government II \\
\hline FPÖ & 9.09 & 21.43 & - & - \\
\hline Lega & 14.87 & 8.96 & 7.23 & - \\
\hline M5S & 24.21 & 25.69 & - & 31.96 \\
\hline Podemos & 22.22 & 18.22 & - & - \\
\hline NZF & 22.92 & 5.43 & - & - \\
\hline
\end{tabular}

subgroups within it) against political actors less frequently in its first government with the Lega, but the percentage increases in the second coalition, exceeding the share of antagonisms from the opposition period. Podemos only slightly decreases its share of antagonist discourses about the people and politicians in government. A substantial decrease in these discourses can only be observed among NZF during its coalition with the centre left. Thus, Hypothesis 5 should be rejected. It should be emphasized that the logic of such antagonisms does not substantially differ in opposition and government. Facebook posts by governing populists mostly change the parties and political actors opposed to the people/the country instead of using a more institutional or formal language associated with own policy implementation. Hence, populist parties still attempt to criticize and sometimes delegitimize political opponents when in power by opposing them to the supposed needs of the population or the country. I have added respective tables in the Online Appendix using the examples of the FPÖ's and Podemos' antagonisms.

We further see no clear decline of antagonisms juxtaposing economic actors and the people when populist parties enter government. Only Podemos and NZF oppose economically powerful groups less often with people and underprivileged groups when in coalition with the centre left. The M5S even increases its share of such discourses in government - especially in coalition with the centre left. Motorway operators (e.g. 11 September 2019), multinational corporations (e.g. 12 November 2019) and rich tax evaders (19 October 2019), among others, are opposed to the people. Even the two radical right parties increase the percentage of messages opposing economic actors and the people when they are in power however, not to a very considerable extent. The Lega and FPÖ generally score very low on messages against economic elites. Both parties further do not seem to juxtapose parts of the native society with non-native outgroups more frequently in opposition, as Figure 1 already suggested. Last, it should be noted that media elites are only juxtaposed with the people by one party, namely the M5S. This is done both in opposition and in government, but not very frequently (mostly twice per period).

The findings indicate that government participation does not tame populist parties' communication as is widely expected in academia. Excluding outgroups, criticizing single political elites and - primarily - creating antagonisms between the people and political, economic or non-native counterparts cannot be observed more frequently in opposition, except for NZF. At this point one might wonder whether the same observation might be valid for non-populist parties as well. Do 
Table 2. Percentages of Antagonism Classified by Targeted Actors

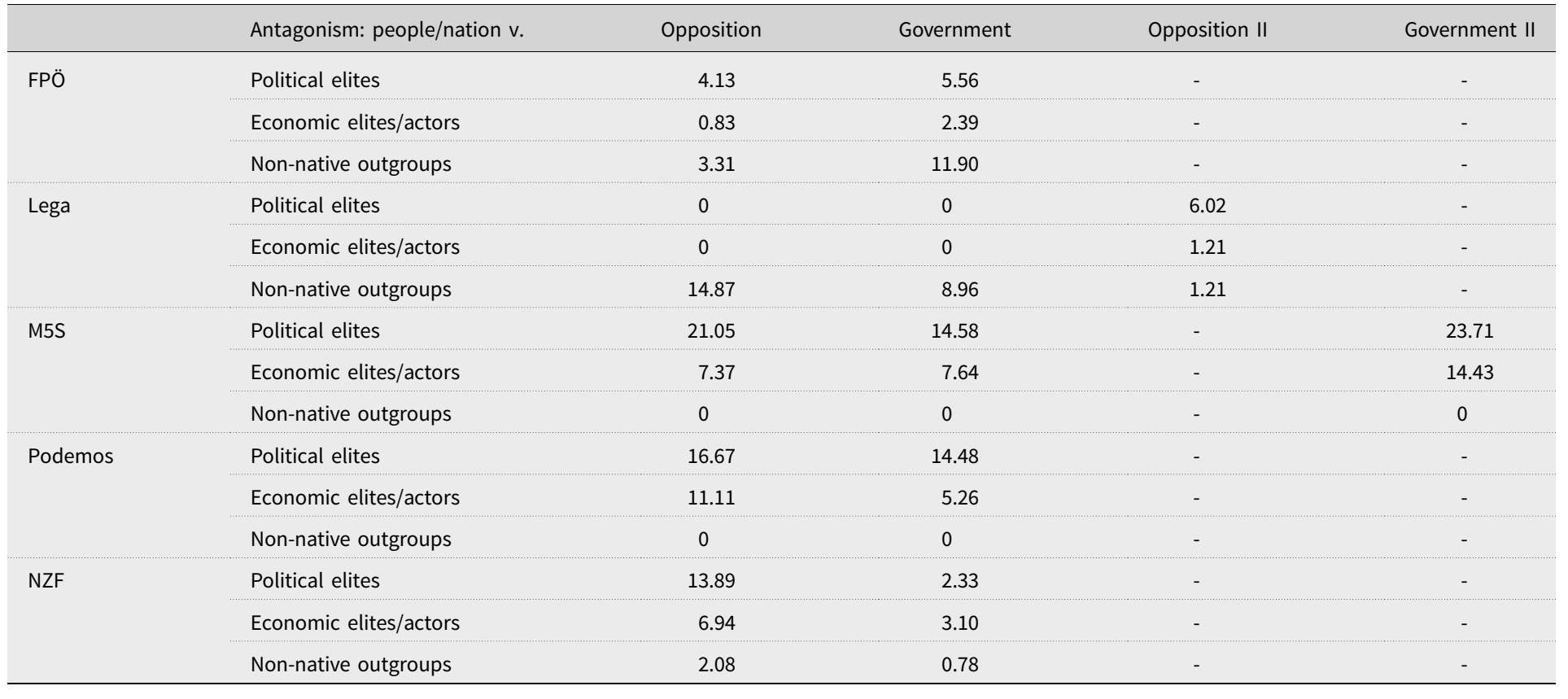


mainstream parties increase their demands and criticisms of elites in opposition? This study does not directly touch upon this question. However, data gathered by Schwörer (2021) from election manifestos of centre-left and centre-right parties in Italy, Spain, Germany and Austria offer at least some first empirical hints. While four parties appear more anti-elitist in opposition, two are more anti-elitist in government (see Online Appendix). Yet these data should not be overestimated. Other variables such as the electoral strength of competing populist parties and shifts in public opinion are identified as main drivers of populist elements in mainstream parties' manifestos (Schwörer 2021). Hence, it can be questioned whether incumbency in general has a considerable effect on political parties' degree of populism.

Does public opinion offer an explanation for the findings of this study as well? Scholars usually associate shifts in public opinion with policy changes by political parties (Fagerholm 2016). For the European countries of this sample, Eurobarometer provides data on trust in political parties, but there are no clear indications that populist parties emphasize anti-elite messages or the conflict between people and political elites when distrust is increasing (Table 3). The M5S increased its anti-elite messages as well as the salience of the people-elite cleavage during its coalition with the centre left. However, distrust in political parties decreased at the same time. Similar observations can be made for the incumbent FPÖ and the Lega in its second opposition period.

As well as shifts in public opinion, electoral losses might lead to an increase in populist messages since they put pressure on parties to change (Akkerman 2016). The M5S (second coalition with centre left), the FPÖ (coalition with ÖVP), Podemos (coalition with centre left) and to a certain degree also NZF (coalition

Table 3. Explanations for Increases of Anti-Elitist, Antagonist and Nativist Elements

\begin{tabular}{llccc}
\hline & & Vote losses & Public opinion & Incumbency \\
\hline \multirow{2}{*}{ Lega } & Pol. anti-elitism & - & - & - \\
& People v. pol. elite & - & - & + - \\
& Nativist elements & - & + & - \\
\hline \multirow{2}{*}{ M5S } & Pol. anti-elitism & $+/-$ & - & + - \\
& People v. pol. elite & + & - & - \\
\hline \multirow{2}{*}{ Podemos } & Pol. anti-elitism & + & - & + - \\
& People v. pol. elite & - & - & + \\
FPö & Pol. anti-elitism & - & - & - \\
& People v. pol. elite & $+/-$ & - & - \\
& Nativist elements & $+/-$ & $+/-$ & - \\
& Pol. anti-elitism & + & $/$ & + \\
\hline NZF & People v. pol. elite & + & $/$ & + \\
\hline & Nativist elements & + & $/$ & + \\
\hline
\end{tabular}

Note: Public opinion refers to distrust in political parties (anti-elitism) and nativist elements refer to negative evaluation of immigration from outside the EU (data from Eurobarometer). + = potential explanation of increases; - = no explanation; $+/-=$ ambiguous (valid for slight increases or specific elements). $/$ = not applicable. 
with Labour) experienced substantial vote losses compared with the vote share predicted by leading opinion polls during the opposition period. ${ }^{11}$ The M5S indeed increased its anti-elite messages and antagonisms a considerable amount after vote losses. The same is true for the percentage of all antagonisms articulated by the FPÖ (yet not for antielitist messages and juxtapositions of political elites with the people). Podemos decreased its amount of anti-elite messages and antagonisms in the face of electoral losses, as did NZF. Yet, in the latter case, the overlap of its governmental status and vote loss make it difficult to determine which explanation is more apt. In sum, vote losses do not seem to predict degrees of populism - at least not in a clear direction. The Lega gained a considerable number of votes in power, which was not reflected in its discourses.

\section{Discussion and conclusion}

This study provided empirical data regarding the question of whether populist parties are more populist in opposition than in office, as is widely assumed in academia. To this end, Facebook profiles of populist parties in three Western European states and New Zealand have been analysed during opposition and governmental periods. The findings rather reject the original assumption. We cannot see a clear trend that populist parties tone down their populist rhetoric once they enter a government coalition. Instead, they remain anti-elitist, relying on negative campaigning against other political actors or former governments. Furthermore, the antagonism between people and political elites also plays an important role for incumbent populist parties. The same is true for nativist messages against supposed non-native outgroups, which even increased slightly within the Facebook posts of the Lega and FPÖ when they came into power. Only the right-wing populist NZF seems to be much tamed during its coalition with the centre-left Labour Party. The fact that the radical right Lega hardly ever emphasizes antagonisms between the people and political elites further suggests that the party might be primarily nativist and hardly populist, conflicting with existing literature in this respect (Albertazzi et al. 2015; Rooduijn et al. 2019).

In sum, governmental status is not a sufficient explanation for the degree of populist elements in populist parties' online communication. Electoral losses and public opinion - often associated with a change in populists' communication do not explain communicative shifts either. So how can shifts in the degree of populism can be interpreted?

Populist communication may be 'a cyclical phenomenon' as described by Luca Manucci and Edward Weber (2017). The quality and quantity of populist messages might depend on developments within the individual countries, which are hardly covered by general assumptions from academic and mostly rational-choice literature. For example, the fact that the Lega increased its share of messages against the government, portraying it as an opponent to the people, could be explained by the end of the coalition with the M5S. This led to increased tension between the M5S and the Lega, reflected in high scores of anti-elitism towards the other party and the government. In Spain, the establishment of Vox as a second populist party (Rooduijn et al. 2019) may have softened Podemos's rhetoric. The salience of specific issues in the public and media (e.g. dominant discourses about corruption) might further affect 'political-discursive opportunities' of populist parties (Caiani 
and Graziano 2019: 1150). Moreover, as mentioned by Benjamin Moffitt (2015: 195), populist parties are not simply passively exposed to exogenous events and developments but 'actively perform and perpetuate a sense of crisis, rather than simply reacting to external crisis'. In this sense, populist parties' communications might depend less on their own electoral performances, public opinion and other external events than on the discourses of other parties.

In conclusion, one should not expect that populist parties' discourses could be tamed by offering them participation in a coalition government. This result has important political implications. Research indicates that nativist or populist discourses also affect public opinion (Wirz et al. 2018). Jörg Matthes and Desirée Schmuck (2017: 571) found that populist advertisements invoke intergroup anxiety and negative stereotypes'. Michael Hameleers and Desirée Schmuck (2017: 1425) revealed that messages blaming immigrants bolstered citizens' negative attitudes towards them 'for those who supported the source of the message'. As long as populist and nativist messages are spread by challenger parties they might not reach the minds of the large majority of the population. However, when incumbent parties articulate these discourses they might become mainstream, capable of unfolding an effect on much larger parts of society. Admittedly, since we are still confronted with a rather low level of populist participation in coalition governments, the conclusion from this study should only be considered as a first empirical contribution to the topic and further does not consider populists in non-coalition governments. Whether populists' government participation will become more common in the future remains to be seen.

Supplementary material. To see the supplementary material for this article, please go to https://doi.org/ 10.1017/gov.2021.2.

\section{Notes}

1 Even studies rejecting the ideological perspective agree on specific discursive or communicative content (Aslanidis 2016).

2 Parties are usually classified as populist according to their statements in political texts such as election manifestos, social media or speeches (Meijers and Zaslove 2020).

3 The author speaks English, French, Spanish, Italian and German.

4 Anti-elitism: 91.67\%, $\mathrm{n}=24$; people-centrism: $87.23 \%, \mathrm{n}=94$; anti-outgroup messages: $100 \%, \mathrm{n}=19$; anti-immigration messages: $85.71 \%, \mathrm{n}=29$.

5 Sample of 50\% coded and 50\% not coded sentences. Anti-elitism: 0.955, $\mathrm{n}=44$; people-centrism: 0.931 , $\mathrm{n}=174$; anti-outgroup messages: $1.0, \mathrm{n}=38$; anti-immigration messages: $0.885, \mathrm{n}=52$.

6 Nativist content could not be identified within posts from Podemos and the M5S.

7 The independent t-test showed that the mean of people-centred messages (all references) is slightly higher in government (36.67) than in opposition (29.04). However, these differences are not statistically significant $(\mathrm{p}>0.05)$ and depend on single parties such as the M5S and FPÖ.

8 The independent t-test showed that the mean of anti-elitist messages (all references) is slightly higher in opposition (35.97) than in government (27.2). However, these differences are not statistically significant $(\mathrm{p}>0.05)$ and strongly depend on the findings from NZF and Podemos.

9 The independent t-test showed that the mean of antagonisms is not higher in opposition (16.76) than in government (18.65) and that these differences are not statistically significant $(\mathrm{p}>0.05)$.

10 The independent t-test showed that the mean of antagonisms between political elites and the people is not higher in opposition (10.29) than in government (10.11) and that the differences are not statistically significant $(\mathrm{p}>0.05)$. The same is true for juxtapositions of economic actors and the people (opposition: 4.58; government: $5.47 ; \mathrm{p}>0.05)$.

11 Based on data from Politico shortly before the respective period of examination. 


\section{References}

Abou-Chadi T (2014) Niche Party Success and Mainstream Party Policy Shifts: How Green and Radical Right Parties Differ in Their Impact. British Journal of Political Science 46(2), 417-436. https://oi. org/10.1017/S0007123414000155.

Akkerman T (2016) Conclusion. In Akkerman T, De Lange SL and Rooduijn M (eds), Radical Right-Wing Populist Parties in Western Europe: Into the Mainstream? London: Routledge, pp. 268-282.

Akkerman T and De Lange SL (2012) Radical Right Parties in Office: Incumbency Records and the Electoral Cost of Governing. Government and Opposition: An International Journal of Comparative Politics 47(4), 574-596. https://doi.org/10.1111/j.1477-7053.2012.01375.x.

Akkerman T, De Lange SL and Rooduijn M (2016) Inclusion and Mainstreaming? Radical Right-Wing Populist Parties in the New Millennium. In Akkerman T, De Lange SL and Rooduijn M (eds), Radical Right-Wing Populist Parties in Western Europe: Into the Mainstream? London: Routledge, pp. 1-28.

Albertazzi D and McDonnell D (eds) (2015) Populists in Power. London: Routledge.

Albertazzi D and Mueller S (2013) Populism and Liberal Democracy: Populists in Government in Austria, Italy, Poland and Switzerland. Government and Opposition: An International Journal of Comparative Politics 48(3), 343-371. https://doi.org/10.1017/gov.2013.12.

Aslanidis P (2016) Is Populism an Ideology? A Refutation and a New Perspective. Political Studies 64(1), 88-104. https://doi.org/10.1111/1467-9248.12224.

Barker F and Vowles J (2020) Populism and Electoral Politics in New Zealand. In Vowles J and Curtin J (eds), A Populist Exception? The 2017 New Zealand General Election. Acton: ANU Press, pp. 9-34.

Berman S (2008) Taming Extremist Parties: Lessons from Europe. Journal of Democracy 19(1), 5-18. https://doi.org/10.1353/jod.2008.0002.

Bernhard L (2020) Revisiting the Inclusion-Moderation Thesis on Radical Right Populism: Does Party Leadership Matter? Politics and Government 8(1), 206-218. http://dx.doi.org/10.17645/pag.v8i1.2515.

Caiani M and Graziano P (2019) Understanding Varieties of Populism in Times of Crises. West European Politics 42(6), 1141-1158. https://doi.org/10.1080/01402382.2019.1598062.

Decker F and Lewandowsky M (2017) Rechtspopulismus in Europa: Erscheinungsformen, Ursachen und Gegenstrategien. Zeitschrift für Politik 64(1), 21-38. https://doi.org/10.5771/0044-3360-2017-1-21.

De Vreese CH et al. (2018) Populism as an Expression of Political Communication Content and Style: A New Perspective. International Journal of Press/Politics 20(9), 423-438. https://doi.org/10.1177/ 1940161218790035.

Donovan T (2020) Misclassifying Parties as Radical Right/Right Wing Populist: a Comparative Analysis of New Zealand First. Political Science 72(1), 58-76. https://doi.org/10.1080/00323187.2020.1855992.

Downs A (1957) An Economic Theory of Democracy. New York: Harper Collins.

Duncan G (2018) Trust, Distrust, and the End of Politics-as-We-Knew-it: The Mood of the Nation Prior to Election 2017. New Zealand Journal of Social Sciences Online 13(2), 114-131. https://doi.org/10.1080/ 1177083X.2017.1355817.

Ernst N et al. (2017) Extreme Parties and Populism: An Analysis of Facebook and Twitter across Six Countries. Information, Communication \& Society 20(9), 1347-1364. https://doi.org/10.1080/ 1369118X.2017.1329333.

Ernst N et al. (2019a) Favorable Opportunity Structures for Populist Communication: Comparing Different Types of Politicians and Issues in Social Media, Television and the Press. International Journal of Press/Politics 24(2), 165-188. https://doi.org/10.1177/1940161218819430.

Ernst N et al. (2019b) Populists Prefer Social Media over Talk Shows: An Analysis of Populist Messages and Stylistic Elements Across Six Countries. Social Media + Society, published early online, January. https://doi.org/10.1177/2056305118823358.

Fagerholm A (2016) Why Do Political Parties Change their Policy Positions? A Review. Political Studies Review 14(4), 501-511. https://doi.org/10.1111/1478-9302.12078.

Fallend F and Heinisch R (2016) Collaboration as Successful Strategy Against Right-Wing Populism? The Case of the Centre-Right Coalition in Austria, 2000-2007. Democratization 23(2), 324-344. https://doi. org/10.1080/13510347.2015.1060223.

Fernández-García B and Luengo ÓG (2018) Populist Parties in Western Europe: An Analysis of the Three Core Elements of Populism. Communication and Society 31(3), 57-76. https://doi.org/10.15581/003.31.3.57-74.

Geer JG (2006) In Defence of Negativity: Attack Ads in Presidential Campaigns. Chicago: University of Chicago Press. 
Green-Pedersen C and Mortensen PB (2015) Avoidance and Engagement: Issue Competition in Multiparty Systems. Political Studies 63(4), 747-764. https://doi.org/10.1111/1467-9248.12121.

Hameleers M (2020) Blaming in the Name of our People: How Attitudinal Congruence Conditions the Effects of Populist Messages Communicated by Traditional Media, Politicians, and Citizens. Media Psychology, published early online, July. https://doi.org/10.1080/15213269.2020.1785314.

Hameleers M and Schmuck D (2017) It's Us Against Them: A Comparative Experiment on the Effects of Populist Messages Communicated via Social Media. Information, Communication \& Society 20(9), 1425-1444. https://doi.org/10.1080/1369118X.2017.1328523.

Haselmayer M (2019) Negative Campaigning and its Consequences: A Review and a Look Ahead. French Politics 17, 355-372. https://doi.org/10.1057/s41253-019-00084-8.

Hawkins KA, Riding S and Mudde C (2012) Measuring Populist Attitudes. C\&M Working Paper 55, https://works.bepress.com/cas_mudde/72/.

Hawkins KA et al. (2019) Measuring Populist Discourse: The Global Populism Database. Paper presented at the 2019 EPSA Annual Conference, in Belfast.

Huber RA and Schimpf CH (2016) Friend or Foe? Testing the Influence of Populism on Democratic Quality in Latin America. Political Studies 64(4), 872-889. https://doi.org/10.1111/1467-9248.12219.

Jagers J and Walgrave S (2007) Populism as Political Communication Style: An Empirical Study of Political Parties' Discourse in Belgium. European Journal of Political Research 46(3), 319-345. https:// doi.org/10.1111/j.1475-6765.2006.00690.x.

Jünger J and Keyling T (2018) Facepager. An Application for Generic Data Retrieval through APIs. Source Code and Releases, https://github.com/strohne/Facepager/.

Krämer B (2017) Populist Online Practices: The Function of the Internet in Right-Wing Populism. Information, Communication \& Society 20(9), 1293-1309. https://oi.org/10.1080/1369118X.2017.1328520.

Krause W and Wagner A (2019) Becoming Part of the Gang? Established and Nonestablished Populist Parties and the Role of External Efficacy. Party Politics, published early online, April. https://doi.org/ 10.1177\%2F1354068819839210.

Landis JR and Koch GG (1977) The Measurement of Observer Agreement for Categorical Data. Biometrics 33(1), 159-174.

Lewis P et al. (2018) Revealed: One in Four Europeans Vote Populist: Exclusive Research Shows how Populists Tripled their Vote over the Past Two Decades. Guardian, 20 November. www.theguardian. com/world/ng-interactive/2018/nov/20/revealed-one-in-four-europeans-vote-populist.

Manucci L and Weber E (2017) Why the Big Picture Matters: Political and Media Populism in Western Europe since the 1970s. Swiss Political Science Review 23(4), 313-334. https://doi.org/10.1111/spsr.12267.

Matthes J and Schmuck D (2017) The Effects of Anti-Immigrant Right-Wing Populist Ads on Implicit and Explicit Attitudes: A Moderated Mediation Model. Communication Research 44(4), 556-581. https://doi. org/10.1177\%2F0093650215577859.

Meijers MJ and Zaslove A (2020) Measuring Populism in Political Parties: Appraisal of a New Approach. Comparative Political Studies, published early online, July. https://doi.org/10.1177/0010414020938081.

Moffitt B (2015) How to Perform Crisis: A Model for Understanding the Key Role of Crisis in Contemporary Populism. Government and Opposition: An International Journal of Comparative Politics 50(2), 189-217. https://doi.org/10.1017/gov.2014.13.

Moffitt B (2017) Populism in Australia and New Zealand. In Rovira Kaltwasser C et al. (eds), The Oxford Handbook of Populism. Oxford: Oxford University Press, pp. 121-139.

Mudde C (2004) The Populist Zeitgeist. Government and Opposition: An International Journal of Comparative Politics 39(4), 541-563. https://doi.org/10.1111/j.1477-7053.2004.00135.x.

Mudde C (2007) Populist Radical Right Parties in Europe. Cambridge: Cambridge University Press.

Müller JW (2016) What is Populism? Philadelphia: University of Pennsylvania Press.

Nai A (2018) Fear and Loathing in Populist Campaigns? Comparing the Communication Style of Populists and Non-Populists in Elections Worldwide. Journal of Political Marketing, published early online, September. https://doi.org/10.1080/15377857.2018.1491439.

Pauwels T (2014) Populism in Western Europe: Comparing Belgium, Germany and the Netherlands. Abingdon: Routledge.

Polk J et al. (2017) Explaining the Salience of Anti-Elitism and Reducing Political Corruption for Political Parties in Europe with the 2014 Chapel Hill Expert Survey Data. Research \& Politics, published early online, January. https:/doi.org/10.1177/2053168016686915. 
Reinemann C et al. (2017) Populist Political Communication. Toward a Model of its Causes, Forms, Effect. In Aalberg T et al. (eds), Populist Political Communication in Europe. New York: Routledge, pp. 12-25.

Rooduijn M and Pauwels T (2011) Measuring Populism: Comparing Two Methods of Content Analysis. West European Politics 34(6), 1272-1283. https:/doi.org/10.1080/01402382.2011.616665.

Rooduijn M, De Lange SL and Van der Brug W (2014) A Populist Zeitgeist? Programmatic Contagion by Populist Parties in Western Europe. Party Politics 20(4), 563-575. https://doi.org/10.1177\% 2F1354068811436065.

Rooduijn M et al. (2019) The PopuList: An Overview of Populist, Far Right, Far Left and Eurosceptic Parties in Europe. http://www.popu-list.org.

Rydgren J (2017) Radical Right-Wing Parties in Europe: What's Populism Got to Do with It? Journal of Language and Politics 16(4), 485-496. https://doi.org/10.1075/jlp.17024.ryd.

Schwörer J (2016) Populismi. Il Movimento 5 Stelle e la Alternativa per la Germania. Rome: Bibliotheka.

Schwörer J (2021) The Growth of Populism in the Political Mainstream: The Contagion Effect of Populist Messages on Mainstream Parties' Communication. Cham: Springer Nature (forthcoming).

Schwörer J and Fernández-García B (2020) Religion on the Rise Again? A Longitudinal Analysis of Religious Dimensions in Election Manifestos of Western European Parties. Party Politics, published early online, July. https://doi.org/10.1177/1354068820938008.

Schwörer J and Romero-Vidal X (2020) Radical Right Populism and Religion: Mapping Parties' Religious Communication in Western Europe. Religion, State and Society 48(1), 4-21. https://doi.org/10.1080/ 09637494.2019.1704611.

Stanley B (2008) The Thin Ideology of Populism. Journal of Political Ideologies 13(1), 95-110. https://doi. org/10.1080/13569310701822289.

Stier S, Posch L, Bleier A and Strohmaier M (2017) When Populists Become Popular: Comparing Facebook Use by the Right-Wing Movement Pegida and German Political Parties. Information, Communication \& Society 20(9), 1365-1388. https://doi.org/10.1080/1369118X.2017.1328519.

Van Spanje J (2011) Keeping the Rascals in: Anti-Political-Establishment Parties and their Cost of Governing in Established Democracies. European Journal of Political Research 50, 609-635. https:// doi.org/10.1111/j.1475-6765.2010.01984.x.

Vowles J (2020) Populism and the 2017 Election: The Background. In Vowles J and Curtin J (eds), A Populist Exception? The 2017 New Zealand General Election. Acton: ANU Press, pp. 35-70.

Walgrave S and De Swert K (2007) Where Does Issue Ownership Come from? From the Party or from the Media? Issue-Party Identifications in Belgium, 1991-2005. Harvard International Journal of Press/ Politics 12(1), 37-67. https://doi.org/10.1177\%2F1081180X06297572.

Williams MH (2018) The Political Impact of the Radical Right. In Rydgren J (ed.), The Oxford Handbook of the Radical Right. Oxford: Oxford University Press, pp. 305-326.

Wirth W et al. (2019) Codebook: NCCRdemocracy Module II: The Appeal of Populist Ideas and Messages. https://osf.io/2z3dk/.

Wirz D et al. (2018) The Effects of Right-Wing Populist Communication on Emotions and Cognitions toward Immigrants. International Journal of Press/Politics 23(4), 496-516. https://doi.org/10.1177\% 2F1940161218788956.

Wolinetz SB and Zaslove A (2018) The Impact of Populist Parties on Party Systems. In Wolinetz SB and Zaslove A (eds), Absorbing the Blow: Populist Parties and their Impact on Parties and Party Systems. London: ECPR Press, pp. 3-23.

Cite this article: Schwörer J (2022). Less Populist in Power? Online Communication of Populist Parties in Coalition Governments. Government and Opposition: An International Journal of Comparative Politics 57, 467-489. https://doi.org/10.1017/gov.2021.2 